\title{
Epiploic Appendicitis at the Hepatic Flexure with Incidentally Detected Acute Appendicitis
}

\section{Tesadüfen Tespit Edilen Akut Apandisit ile Hepatik Köşe Yerleşimli Epiploik Apandisit}

\author{
(1) Tolga Kalaycı \\ Erzurum Regional Training and Research Hospital, Clinic of General Surgery, Erzurum, Turkey
}

\begin{abstract}
HIIIIII| ABSTRACT
Epiploic appendicitis (EA) is a rare cause of abdominal pain that is mostly treated with medical treatment. However, in some cases, surgery is required for recovery. In this case report, a case of EA and acute appendicitis, detected simultaneously, is presented. A 32-year-old-man who had tenderness and rebound at right upper quadrant was admitted to emergency department. In computed tomography scan, there was an inflamed area around the hepatic flexure, and the appendix was normal. Diagnostic laparoscopy was planned because the patient was not relieved by medical treatment. Resection of necrotic tissues was performed together with appendectomy. The patient was discharged on the seventh day of his admission because his oral intake was normal, his abdominal examination was comfortable, and his inflammatory parameters decreased to normal levels. In the pathological evaluation of the operation specimen, acute appendicitis, localized peritonitis and necrotic EA were observed.
\end{abstract}

Keywords: Appendicitis, diagnostic laparoscopy, epiploic appendicitis, medical treatment

\section{||||||||||| ÖZ}

Epiploik apandisit (EA), çoğunlukla medikal tedavi ile tedavi edilen nadir bir karın ağrısı nedenidir. Bununla birlikte, bazı durumlarda iyileşme için ameliyat gerekir. Bu olgu sunumunda eş zamanlı olarak saptanan EA ve akut apandisit olgusu sunulmaktadır. Sağ üst kadranda hassasiyet ve rebound olan 32 yaşında erkek hasta acil servise başvurdu. Bilgisayarlı tomografi taramasında hepatik fleksura çevresinde iltihaplı bir alan vardı ve apendiks normaldi. Hasta medikal tedavi ile rahatlamadığı için tanısal laparoskopi planlandı. Apendektomi ile birlikte nekrotik dokularının rezeksiyonu yapıldı. Hasta yatışının yedinci gününde oral alımının normal olması, karın muayenesinin rahat olması ve inflamatuar parametrelerinin normale dönmesi nedeniyle taburcu edildi. Ameliyat piyesinin patolojik değerlendirmesinde akut apandisit, lokalize peritonit ve nekrotik EA gözlendi.

Anahtar Kelimeler: Apandisit, tanısal laparoskopi, epiploik apandisit, medikal tedavi

\section{Introduction}

Epiploic appendicitis (EA), is the inflammation of small peritoneal sacs (epiploic appendices) filled with fat and capillaries, which extend outward from the serosal surface of the colon. ${ }^{1}$ It is a rare condition of abdominal pain caused by occlusion of the vessels draining the epiploic appendix due to thrombus or torsion. ${ }^{2}$ Clinical findings of EA are abdominal pain and tenderness detected on physical examination. Diagnosis of EA may be confirmed by imaging methods. While most cases of EA are treated medically, in rare cases surgical intervention is required. ${ }^{3}$

Here we present a case of EA with concurrent acute appendicitis. Acute appendicitis was not detected preoperatively by imaging, but was discovered during intraoperative evaluation.

Address for Correspondence/Yazışma Adresi: Tolga Kalaycı, MD,

Erzurum Regional Training and Research Hospital, Clinic of General Surgery, Erzurum, Turkey

E-mail: dr.tolgakalayci@gmail.com ORCID ID: orcid.org/0000-0002-6977-1757

Received/Geliş Tarihi: 17.04.2021 Accepted/Kabul Tarihi: 31.05.2021 


\section{Case Report}

A 32-year-old-man was admitted to the emergency department of Igdir City Hospital with abdominal pain and nausea which had persisted for two days before admission. There was no history of additional disease or surgery. On evaluation, vital signs were: blood pressure 134/72 mmHg; pulse rate 108 beats per minute; oxygen saturation on room air 96\%; and body temperature $37.7^{\circ} \mathrm{C}$. On abdominal physical examination, there was tenderness and rebound at the right upper quadrant.

Blood test results were normal except for high C-reactive protein (CRP) (65 mg/L) and high leukocyte count $\left(14 \times 10^{3} /\right.$ $\mathrm{mm}^{3}$ ). On computed tomography (CT) scan, there was an inflamed area around the hepatic flexure (Figure 1), and the appendix was normal (Figure 2). The patient was hospitalized with a pre-diagnosis of epiploic appendicitis. Oral intake was stopped, and intravenous hydration was started. A third-generation cephalosporin, Ceftriaxone 2x1 gr/day and Metronidazole 3x500 mg/100 mL/day were given. Daily abdominal examination was performed. On the third day of admission, the patient reported increased abdominal pain and inflammatory parameters were further elevated with leukocyte count $16 \times 10^{3} / \mathrm{mm}^{3}$ and CRP concentration $110 \mathrm{mg} / \mathrm{L}$. Abdominal ultrasonography (USG) was performed and were consistent with CT findings. Diagnostic laparoscopy was performed. On exploration, a long, inflamed appendix tissue with increased vascularity was observed and was compatible with acute appendicitis (Figure 3). Approximately $200 \mathrm{cc}$ of seropurulent fluid had accumulated in the pelvis. In addition, the epiploic appendix in the region of the hepatic flexure was seen to be adherent to the abdominal wall, and was severely inflamed

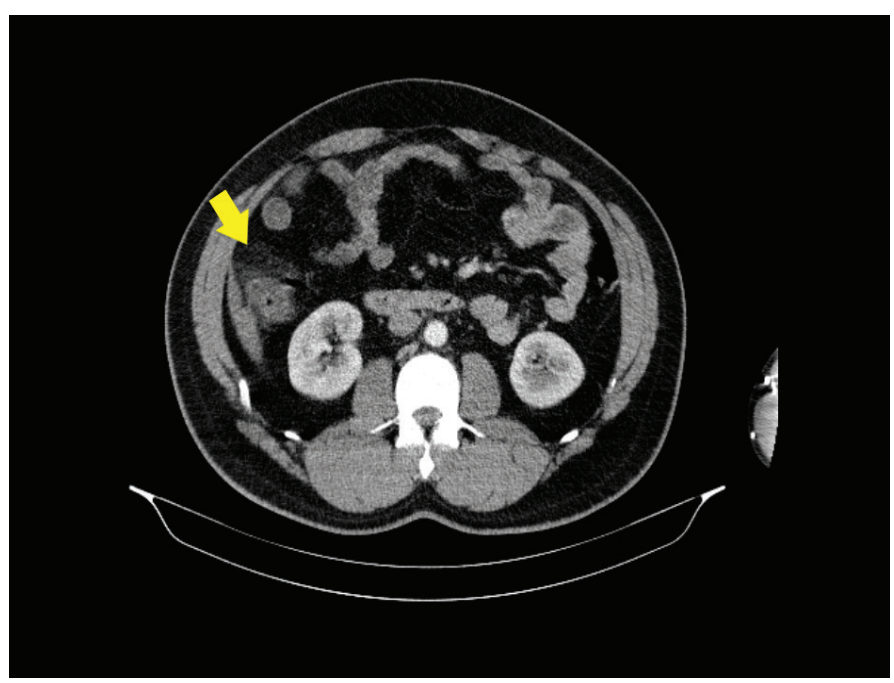

Figure 1. A 32-year-old-man with abdominal pain was admitted to the emergency department. CT scan showed an inflamed area around the hepatic flexure at the liver border

CT: Computed tomography and necrotic (Figure 4 and 5). All necrotic tissues were removed, appendectomy was performed, and seropurulent fluid accumulated in the pelvis was aspirated. One drain was placed in the subhepatic area in order to give an early indication of any colonic leak. A further drain was placed in the Douglas's pouch to drain seropurulent fluid accumulated in the pelvis.

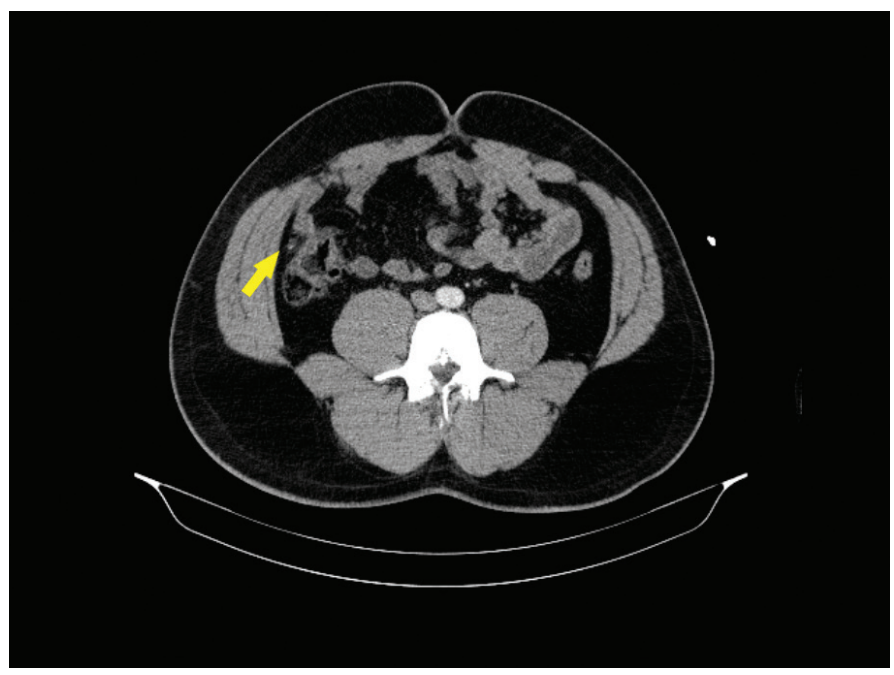

Figure 2. Normal appendix tissue on CT scan CT: Computed tomography

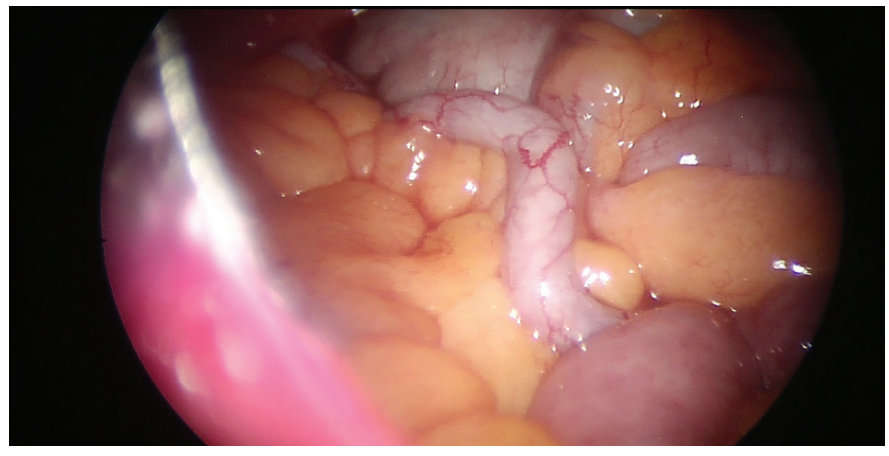

Figure 3. Intra-operative image of appendix vermiformis showing inflamed appendix tissue with increased vascularity

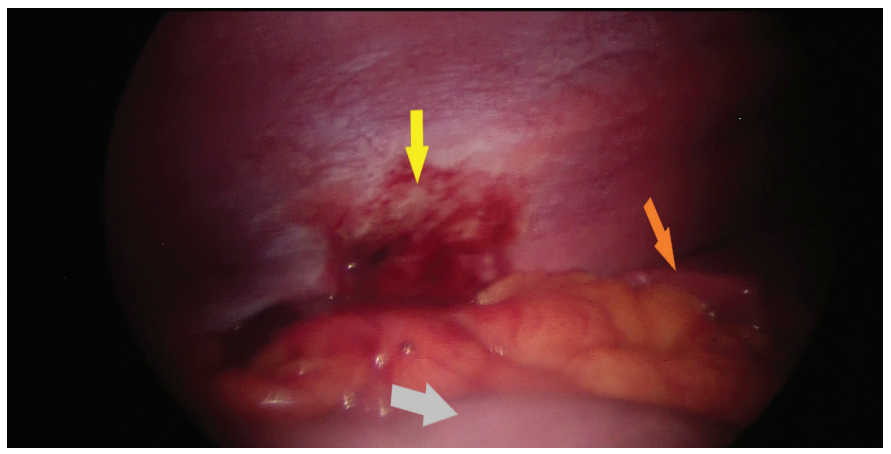

Figure 4. Inflamed abdominal lateral wall (yellow arrow shows inflamed abdominal lateral wall, orange arrow shows inferior border of the liver, and grey arrow shows right colonic segment) 
After the operation, the patient was followed in the ward. Preoperative antibiotic therapy was continued postoperatively. Oral feeding was reinstated six hours after the operation. Drains were removed on the third postoperative day. The patient was discharged on the seventh day of his admission because his oral intake was normal, his abdominal examination was comfortable, and his inflammatory parameters decreased to normal levels. Histopathological evaluation of the operation specimen reported acute appendicitis, localized peritonitis and necrotic EA (Figure 6 and 7).

\section{Discussion}

Epiploic appendix was first described by Vesalius in 1543 as fat bags covered with serosa around colon segments. ${ }^{1}$ EA was described by Dockerty et al. ${ }^{4}$ as an ischemic inflammatory condition without inflammation of adjacent organs. Blood supply to the epiploic appendix is from branches of the colic artery and is weak. EA usually arises due to torsion of draining veins of epiploic appendices. It is frequently seen in the sigmoid colon, descending colon and cecum due to the longer epiploic extensions. There are 50-100 epiploic

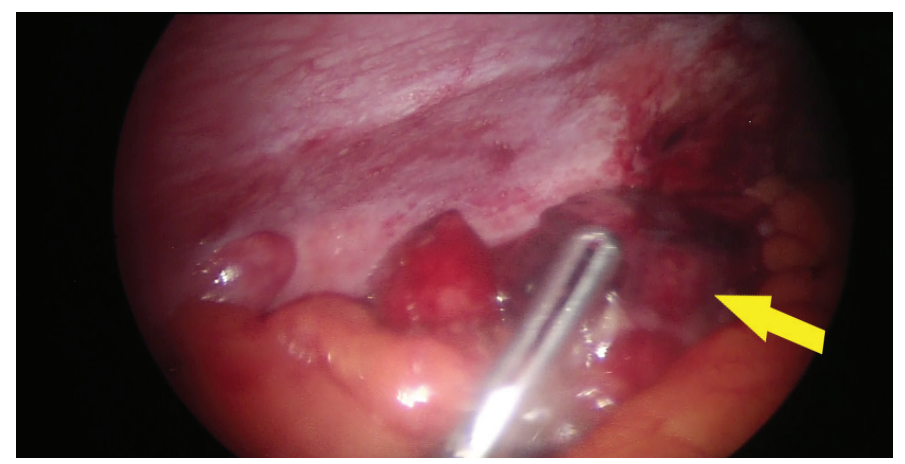

Figure 5. Yellow arrow shows necrotic and severely inflamed epiploic appendix

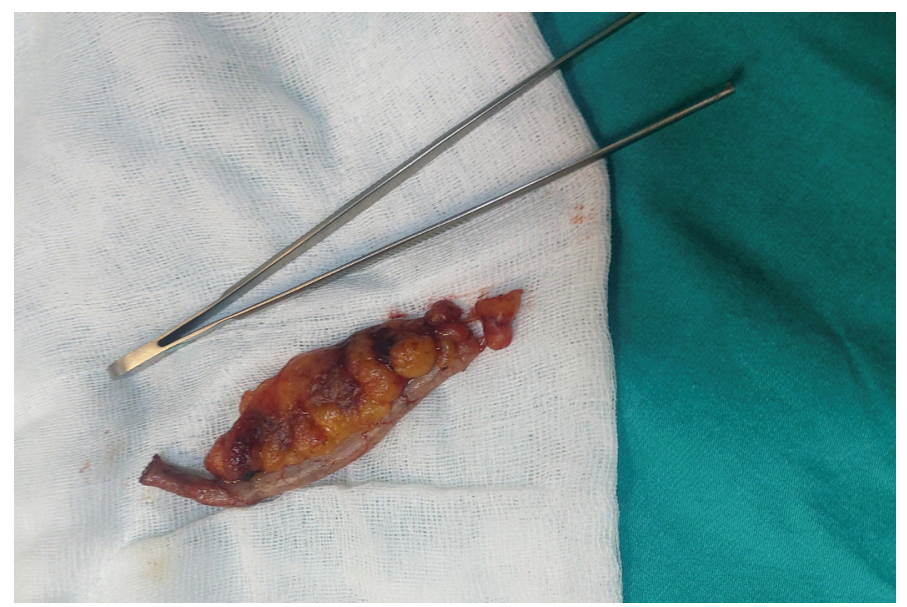

Figure 6. Appendix specimen: A long, inflamed tissue with increased vascularity appendices around all the colonic segments and 57\% of them are located in the rectosigmoid region. ${ }^{5}$

In this case, a patient with EA and incidentally detected acute appendicitis is presented. The appendix was normal on initial CT scan. During hospital admission acute appendicitis was added to the clinical picture, due to the progression of inflammation in the epiploic appendices across the paracolic distance or through bacterial translocation. However, the definitive etiology of acute appendicitis was not primarily known.

EA is more common in men aged 40-50, but it can be seen at all ages. ${ }^{1,6}$ The incidence of EA is reported to be 8.8 per $1,000,000 .{ }^{7}$ Patients normally present with a sudden onset of abdominal pain that mimics acute diverticulitis. On physical examination, tenderness is the most common finding, while defense and rebound are not usually observed. A palpable mass may be detected in $10-30 \%$ of patients. ${ }^{8}$ EA does not have any pathognomonic diagnostic laboratory findings. However, leukocytosis and increased CRP can be seen. ${ }^{9}$ In the past most cases of EA were incidentally diagnosed during laparotomy. However, with advances in imaging techniques it is now possible to diagnose EA through imaging. It can be difficult to diagnose EA using USG alone and CT is the most important imaging tool for diagnosing EA. Characteristic CT findings are an oval fatty lesion surrounded by a ring with inflammatory changes. ${ }^{10}$

EA is a benign condition that can heal spontaneously in less than 10 days with the use of antibiotics. Surgical intervention may be required in cases where complications, such as intestinal obstruction, adhesion, abscess, and peritonitis, develop. Also, in cases of persistent symptoms and failure of conservative treatment, the patient will still need laparoscopic resection of the inflamed tissue. In cases of surgical treatment, diagnostic laparoscopy was used to find

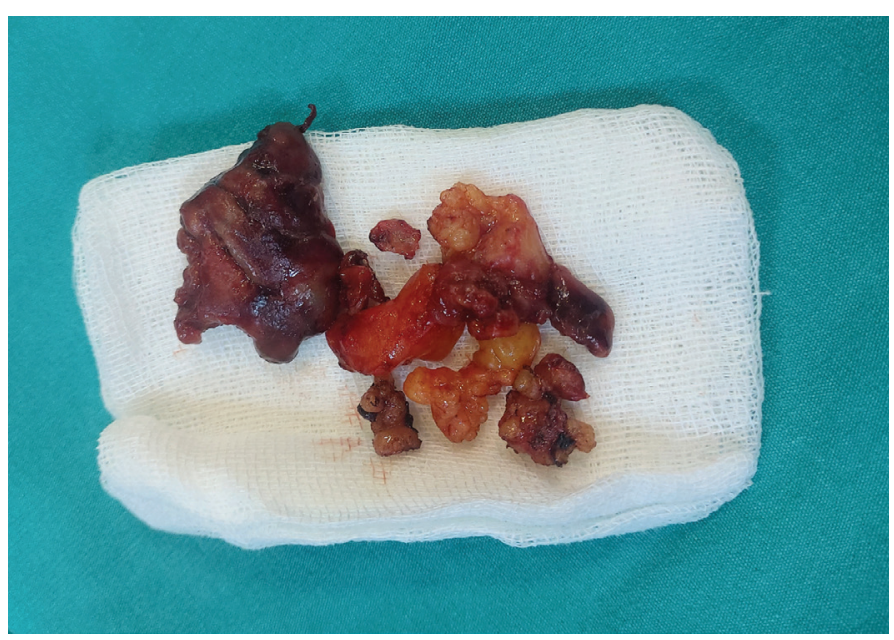

Figure 7. Inflamed epiploic appendix with necrosis 
and identify the main pathology as diagnostic laparoscopy allows evaluation of the whole abdominal cavity and helps to find additional pathologies. During laparoscopy, the surgeon's experience and technical facilities are important factors. Due to the lack of experience of the surgeon in laparoscopy and technical difficulties, open surgery should be applied at first step. During the operation, all necrotic and inflamed tissues should be removed and existing additional pathologies should be corrected.

Recurrence is an important issue in EA. Sand et al. ${ }^{2}$ reported a $40 \%$ recurrence rate after conservative treatment. It should be kept in mind that recurrence may develop after conservative treatment and surgical intervention may be required later.

In conclusion, EA is a rare condition that can cause acute abdomen. CT is helpful in diagnosis and most EA cases are treated conservatively. However, in some cases, surgery is required for recovery. We recommend laparoscopy in firstline surgery to ensure a general abdominal exploration, and the diagnostic laparoscopy option should be considered in patients whose abdominal examination is not relieved and in whom inflammatory markers remain elevated.

\section{Ethics}

Informed Consent: The patient provided an informed consent.

Peer-review: Externally peer reviewed.

Financial Disclosure: The author declared that this study received no financial support.

\section{References}

1. Aslaner A, Çakır T, Gündüz UR, Mayir B, Bülbüller N. Primary epiploic appendagitis: Case report. Selcuk Medical Journal 2016;32:49-50.

2. Sand M, Gelos M, Bechara FG, Sand D, Wiese TH, Steinstraesser L, Mann B. Epiploic appendagitis-clinical characteristics of an uncommon surgical diagnosis. BMC Surg 2007;7:11.

3. Güner M, Damburac1 N. Primary Epiploic Appendicitis Treated Conservatively: Case Report and Review of the Litareture. Aegean J Med Sci 2018;1:19-21.

4. Lynn T. A clinicopathologic study of the epiploic appendages. Surg Gynecol Obst 1956;103:423-433.

5. Saad J, Mustafa HA, Elsani AM, Alharbi F, Alghamdi S. Primary epiploic appendagitis: reconciling CT and clinical challenges. Indian J Gastroenterol 2014:33:420-426

6. Choi YU, Choi PW, Park YH, Kim JI, Heo TG, Park JH, Lee MS, Kim $\mathrm{CN}$, Chang SH, Seo JW. Clinical characteristics of primary epiploic appendagitis. J Korean Soc Coloproctol 2011;27:114-121.

7. De Brito P, Gomez M, Besson M, Scotto B, Huten N, Alison D. Frequency and epidemiology of primary epiploic appendagitis on CT in adults with abdominal pain. J Radiol 2008;89:235-243.

8. Legome EL, Sims C, Rao PM. Epiploic appendagitis: adding to the differential of acute abdominal pain. J Emerg Med 1999;17:823-826.

9. Nagaich N, Sharma R, Singh M. Primary epiploic appendagitis: A diagnostic challenge, clinical spectrum and experience from a tertiary centre. IJCAR 2015:4:482-484

10. McClure MJ, Khalili K, Sarrazin J, Hanbidge A. Radiological features of epiploic appendagitis and segmental omental infarction. Clin Radiol 2001;56:819-827. 